\title{
1. DEEP SEA DRILLING PROJECT LEG 92, SOUTHEAST PACIFIC OCEAN: INTRODUCTION, CRUISE NARRATIVE, PRINCIPAL RESULTS, AND EXPLANATORY NOTES ${ }^{1}$
}

\author{
Margaret Leinen, Graduate School of Oceanography, The University of Rhode Island \\ David K. Rea, Department of Atmospheric and Oceanic Science, The University of Michigan \\ and \\ Keir Becker, Scripps Institution of Oceanography ${ }^{2}$
}

\section{INTRODUCTION}

During the past decade, major advances in our understanding of ocean chemical processes have followed the discovery and ensuing investigation of seafloor hydrothermal activity. Fissures and fractures form in fresh ridge-crest basalt as it cools and is rifted apart. The fractures provide conduits for the circulation of cold bottom water into the underlying crust. The circulating seawater penetrates to a depth of a few kilometers, reacts chemically with hot basalt at temperatures in excess of $300^{\circ} \mathrm{C}$, and emerges as hot springs along the ocean floor. The chemical exchanges that occur during this process include the removal from the water of magnesium and sulfate and the enrichment of the water in iron, manganese, calcium, silica, potassium, and other trace elements. Although these hydrothermal fluxes are still poorly known, it is clear that the fluxes of some of the elements involved in hydrothermal activity, like $\mathrm{Mg}$, are of the same order of magnitude as the riverine flux and thus of equivalent importance in ocean chemical cycles and budgets.

The realization that ridgecrest hydrothermal activity is more common along the faster spreading centers of the Pacific Ocean than along the slowly spreading MidAtlantic Ridge has given rise to a generally accepted correlation between the intensity of this activity and seafloor spreading rate. Knowledge of seafloor hydrothermal activity is essential to our understanding of the oceanic cycling of elements, and an understanding of the history of hydrothermal activity is important to ocean paleochemistry and many other aspects of the history of the Earth and the oceans.

Leg 92 was undertaken primarily to determine the nature and history of basalt-seawater (or hydrogeology) interactions at and on the flanks of the East Pacific Rise (EPR). The sites surveyed (in February and March of 1982) as potential drill sites for the leg lay west of the EPR crest and at $19^{\circ} \mathrm{S}$ (Fig. 1). Placing the transect at $19^{\circ} \mathrm{S}$ made it possible to investigate hydrothermal activity at the fastest-spreading portion of the world's rift sys-

\footnotetext{
${ }^{1}$ Leinen, M., Rea, D. K., et al., Init. Repts. DSDP, 92: Washington (U.S. Govt. Printing Office).

2 Addresses: (Leinen) Graduate School of Oceanography, The University of Rhode Island, Narrangansett, RI 02882; (Rea) Oceanography Program, Department of Atmospheric and Oceanic Science, The University of Michigan, Ann Arbor, MI 48109; (Becker) Deep Sea Drilling Project, Scripps Institution of Oceanography, La Jolla, CA 92093 (present address: Division of Marine Geology and Geophysics, University of Miami, Miami, FL 33149).
}

tem while avoiding excessive dilution of the hydrothermal sediment component by either terrigenous or biogenic sediment and the resulting complication of the pore water and sediment chemistry by the reducing conditions associated with organic diagenesis. To relate hydrothermal fluid and sediment chemistry to the basalt crust and its structure, we planned to drill a re-entry hole to recover samples of and to complete a logging program in the basalts, which despite their proximity to a fast-spreading ridge were old enough to have undergone alteration. We planned to recover some basalt from each drill site for comparison. The logging program was designed to continue the efforts of the site surveys to locate evidence of ridgeflank hydrothermal activity and included the measurement of heat flow and the analysis of pore waters for evidence of fluid advection. A final objective of Leg 92 was to reoccupy Hole 504B, the deep re-entry site in the Panama Basin, for the purpose of downhole temperature measurement, water sampling, a borehole-seismometer refraction survey, and logging and packer experiments.

\section{CRUISE NARRATIVE}

Leg 92 of the Deep Sea Drilling Project traversed the southeast Pacific Ocean from Papeete, Tahiti, to Balboa, Panama (4621 mi. [8558 km]; Fig. 1). The Glomar Challenger sailed from Papeete on 23 February 1983 and arrived at the entrance to the Panama Canal on 18 April. Shortly after leaving Tahiti, the ship encountered typhoon Nisha, which had 70-knot winds and 30-ft seas and slowed progress considerably for 3 days. The lost time was made up during the remainder of the cruise because the early months of 1983 were characterized by a strong El NiñoSouthern Oscillation, and we rarely experienced the customary 10- to 20-knot trade winds (winds even came from the west at times). The consistent lack of headwinds allowed the Glomar Challenger, with its large sail area, to steam 1 to 2 knots faster than planned. Unusual atmospheric conditions were also responsible for our two sightings of the green flash.

In the early afternoon of April 7, 1983, at latitude $00^{\circ} 00^{\prime} 00^{\prime \prime} \mathrm{N}$ (or S), longitude $84^{\circ} 40^{\prime} \mathrm{W}$ we were boarded by Neptunus Rex and the Royal Family. In the ceremony that followed, the last to be held on the Glomar Challenger, those voyagers uninitiated in the ways of the sea were subjected to appropriate rituals, inducted into the Solemn Mysteries of the Ancient Order of the Deep, and became Shellbacks (Fig. 2). 


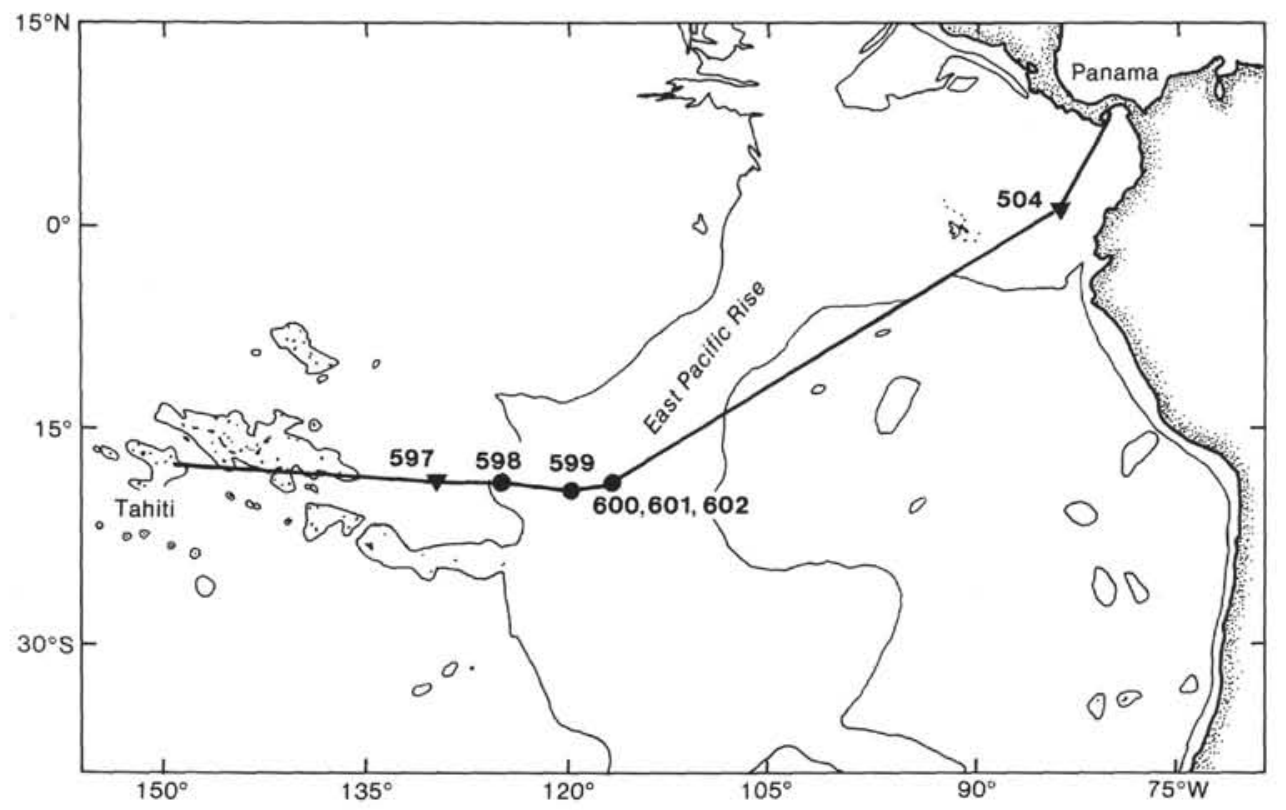

Figure 1. Location of Glomar Challenger Leg 92 trackline and drill sites in southeast Pacific Ocean. Inverted triangle denotes re-entry site.

Leg 92 cored 19 holes at six sites. Most of the sediments were recovered with the variable-length hydraulic piston corer (VLHPC) or the extension core barrel (XCB). The XCB was used at most sites in an effort to recover the sediment/basement contact and to drill into basalt without tripping the drill string to change bits. Standard rotary bits were used at Holes 597B and 597C (the pilot and re-entry holes at the oldest site), where basalt drilling was relatively trouble free and recovery was high. Three holes (598A, 599A, and 601A) were devoted entirely to downhole experiments (in situ pore water drilling and sediment temperature measurements for heat flow calculations); no sediment recovery was attempted at these locations. Drilling these holes solely for downhole experiments improved the downhole experimental data, reduced the drilling disturbance of recovered sediment, and took very little additional time in the thin sediment sections we were coring.

At Sites 600,601 , and 602 we encountered a variety of problems, all of which arose from the thinness $(0$ to $25 \mathrm{~m}$ ) of the sedimentary section. Because the VLHPC cores penetrated only a few meters of sediment before hitting hard rock, several VLHPC barrels sheared off, one VLHPC barrel stuck in the bit, recovery was poor, and the sediment was disturbed.

The site survey cruise, Ariadne II, used bottom transponders to determine the precise position of the heat flow, pore water, and coring stations and left transponders in three of the regions surveyed for use by the Glomar Challenger. We found the Glomar Challenger to be an ideal ship for this kind of precise target work, because the ship's dynamic positioning system allowed precise ship moves within the transponder network.

Hole 504B, the deepest hole ever drilled in ocean crust, was spudded during Leg 69 and deepened during Legs 70 and 83 to a below sea level depth of $4823.5 \mathrm{~m}$ ( $1350 \mathrm{~m}$ below the seafloor and $1075.5 \mathrm{~m}$ into the basal- tic crust). Because Hole 504B provides earth scientists with a unique opportunity to increase the understanding of the geology, geophysics, and geochemistry of ocean crust, Leg 92 visited the hole for 9 days at the end of the cruise to conduct a series of geothermal, geochemical, and geophysical experiments.

\section{PRINCIPAL RESULTS}

The sediment recovered at Holes 597, 597A, and 597C consisted of $52.7 \mathrm{~m}$ of clay-bearing to clayey nannofossil ooze of late Oligocene through early Miocene age, which lay beneath a thin zeolitic clay layer (Fig. 3). Hole $597 \mathrm{C}$, the re-entry hole, penetrated $91 \mathrm{~m}$ into a series of massive basalt flows and recovered $48.5 \mathrm{~m}$ of rock. The drilling in this hole is the most successful yet achieved in basement in fast-spreading crust. The recovered rocks are generally olivine-free to olivine-poor aphyric basalts that display three distinct stages of alteration: an early, possibly deuteric stage; a later non-oxidative stage characterized by dark green smectite, sulfides, and a small amount of native copper; and a final oxidative stage including calcite and smectites and oxyhydroxides. Successful caliper and borehole televiewer logging runs showed variations in formation fracturing that correlate with both the recovery and the petrology of the basalt.

The sedimentary section drilled at Site 598 consisted of $44.6 \mathrm{~m}$ of Pleistocene to latest early Miocene claybearing to clayey nannofossil ooze. The ooze overlay $7.8 \mathrm{~m}$ of foraminifer-bearing nannofossil chalk and limestone, in which the hole ended (Fig. 3). Sediments accumulated much more slowly during the Pliocene/Pleistocene $(\approx 1 \mathrm{~m} / \mathrm{m} . \mathrm{y}$.) than during the Miocene $(\approx 3$ to 8 $\mathrm{m} / \mathrm{m} . \mathrm{y}$.$) .$

The coring at Holes 599 and 599B penetrated $41 \mathrm{~m}$ of clayey and clay-bearing nannofossil ooze, much of it extensively reworked, and $9 \mathrm{~m}$ of pillow basalt. The sediments are late Miocene to Pleistocene in age (Fig. 3). 


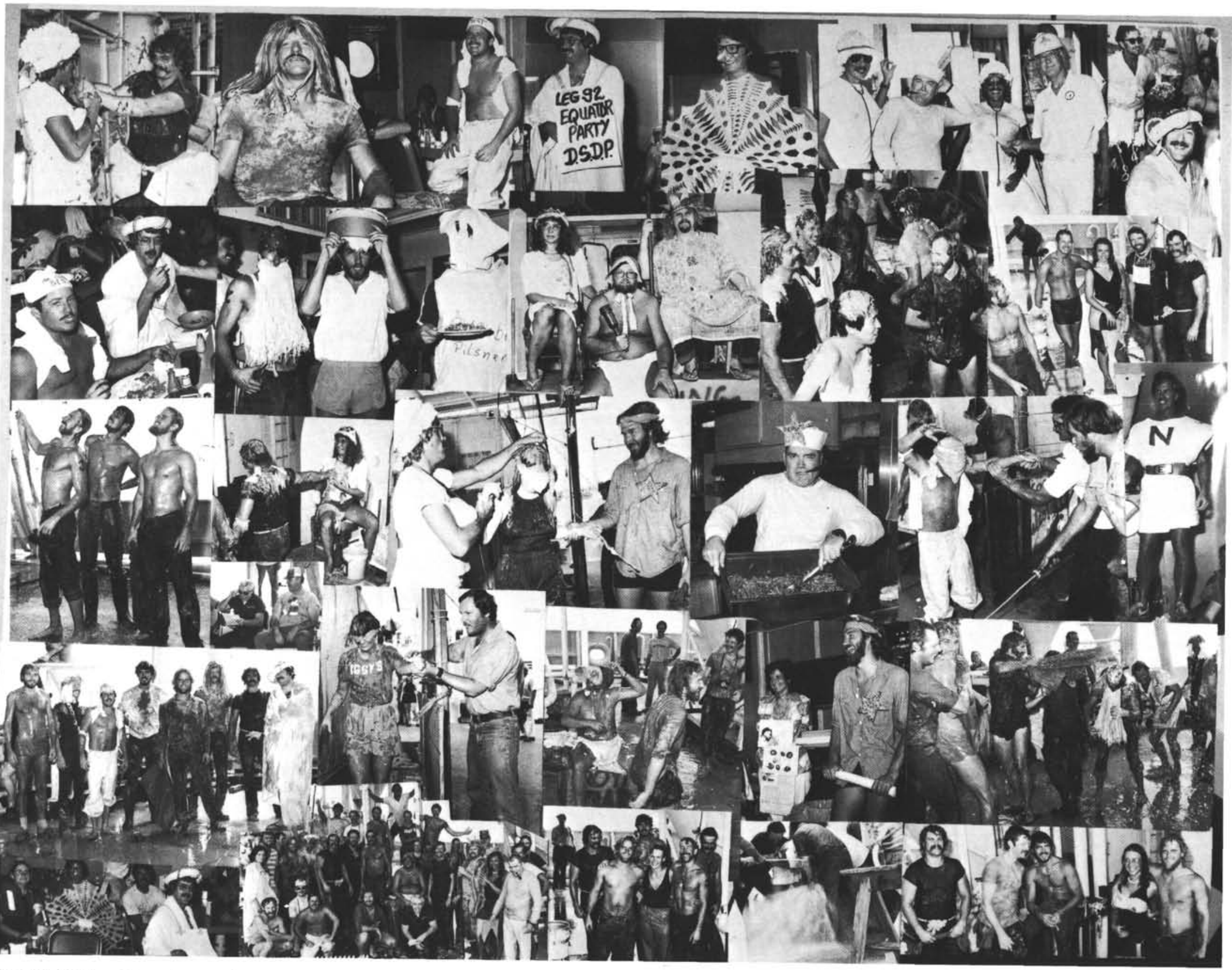

Figure 2. The Leg 92 equator crossing ceremony, last and best of those conducted aboard the Glomar Challenger. 

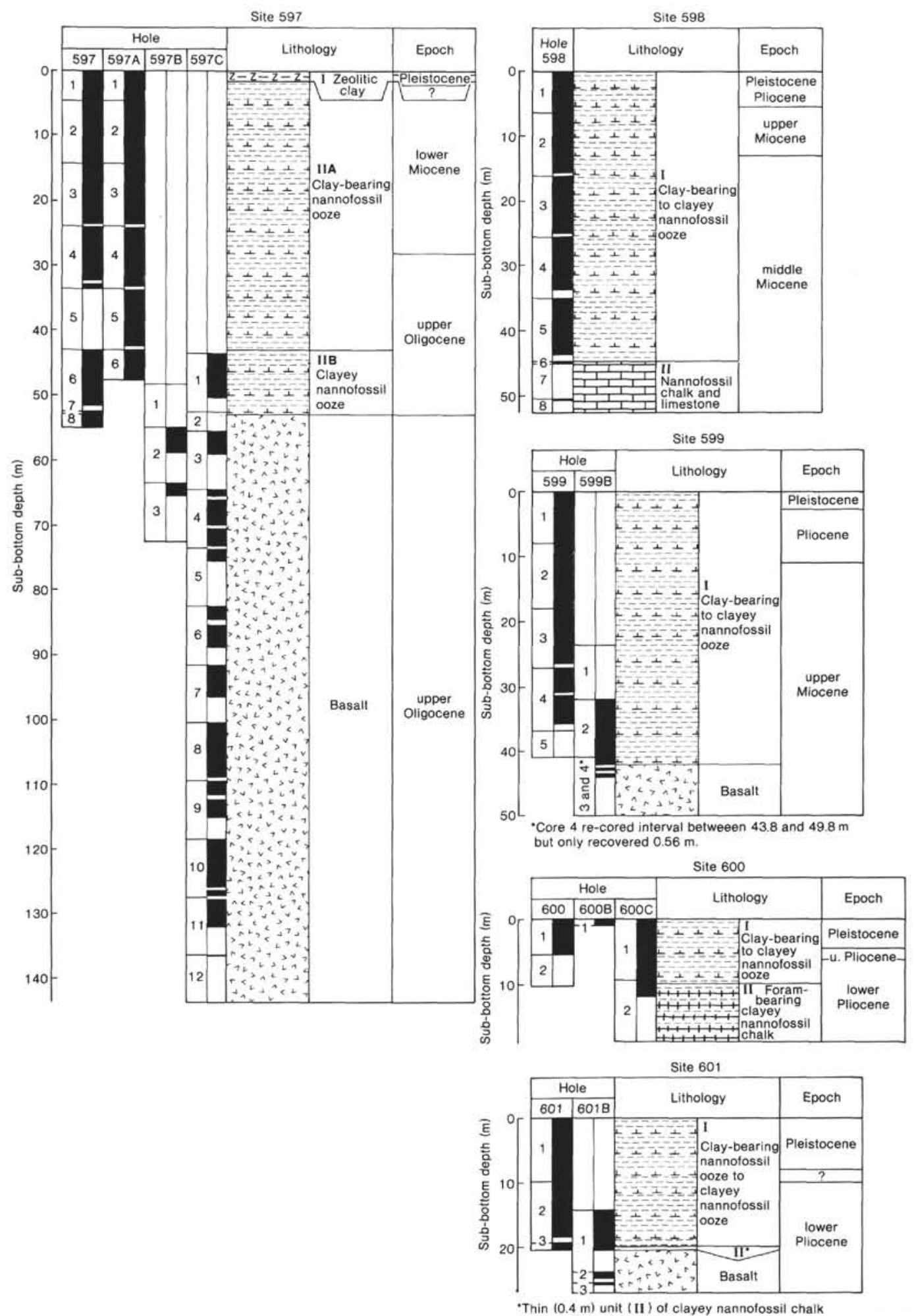
to nannofossil claystone.

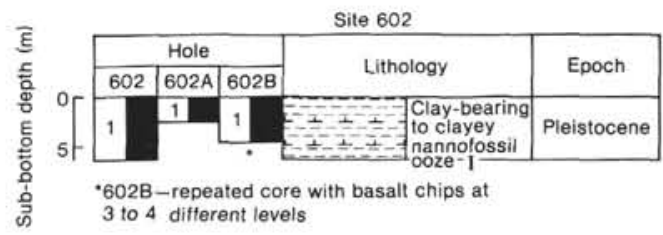

Figure 3. Lithology, age, and recovery of sediment and rock at Sites 597 to 602 . 
Basalt cobbles recovered from Hole 599B are transitional between olivine-poor tholeiites and ferrobasalts, with altered outer rims and fairly fresh interiors.

Sites 600,601 , and 602 were drilled in young, very thin sediment cover in areas that the site surveys indicated were characterized by high, intermediate, and low heat flow, respectively. At Site 600, the high heat flow site, the best hole $(600 \mathrm{C})$ recovered $10 \mathrm{~m}$ of Pliocene to Pleistocene clay-bearing to clayey nannofossil ooze that overlay $1.8 \mathrm{~m}$ of Pliocene foraminifer-bearing clayey nannofossil ooze (Fig. 3). Low accumulation rates and increased amounts of reworking characterize the upper Pliocene sediments there and also at Site 601 .

Site 601 , in an intermediate heat flow area, yielded the thickest section of the three young drill sites: $20 \mathrm{~m}$ of clay-bearing to clayey nannofossil ooze and foraminifer-nannofossil clay overlay a thin $(0.4-\mathrm{m})$ chalky layer. Sediments are Pliocene to Pleistocene in age. The late Pliocene sediments are reworked. Hole 601B penetrated $3.1 \mathrm{~m}$ into basement and recovered about $1 \mathrm{~m}$ of fresh vesicular ferrobasalt fragments (Fig. 3).

The only useful core from Site 602, the low heat flow target, is from Hole $602 \mathrm{~A}$ and contains $2.3 \mathrm{~m}$ of Pleistocene clay-bearing to clayey nannofossil ooze.

At Hole 504B, we took temperature measurements and water samples while the borehole waters were still undisturbed. The resulting temperature profile documents a decrease in the rate at which water is flowing downhole to an underpressured aquifer that exists in the uppermost $100 \mathrm{~m}$ of basalt. Since Leg 83 (Nov. 1981), the downhole flow rate has decreased from $25 \mathrm{~m} / \mathrm{hr}$. to 2 to $3 \mathrm{~m} / \mathrm{hr}$. The temperature at the bottom of the hole is 155 to $165^{\circ} \mathrm{C}$.

The borehole water should provide a natural laboratory for the evaluation of basalt-seawater reactions at elevated temperatures. Shipboard chemical analyses showed a linear relationship between decreasing $\mathrm{Mg}$ and increasing $\mathrm{Ca}$ when the latter is corrected for anhydrite precipitation using the sulfate concentration. The analyses further confirmed that the reaction is also balanced by $\mathrm{Na}$ and $\mathrm{K}$, which are removed during alteration reactions. Unfortunately, since the borehole was contaminated with bentonite drilling mud, many of the reactions are probably dominated by the alteration of bentonite rather than the alteration of basalt.

Several downhole experiment programs addressed the relationship between hydrothermal flow and the density and distribution of crustal fractures. An oblique seismic experiment on a regional scale was carried out in which the Glomar Challenger recorded the responses of a seismometer clamped in the borehole to shots made in both radial and circular patterns by the Ellen B. Scripps. The experiment detected anisotropy from the seismic wave arrivals which appears to be related to regional crustal inhomogeneities.

In a smaller-scale experiment, a multichannel sonic tool was used to study the sonic velocities and waveforms in Layer 2A (which encompasses the underpressured zone). The shape of the waveforms proved to be related to the amount of fracturing in the rock, which had previously been detected by a borehole televiewer.

\section{SITE CHAPTER AUTHORSHIP}

The results of the work at each site are presented in more detail in the site chapters. The following members of the scientific party wrote some or all of the specified sections of the site chapters:

Principal results: Leinen, Rea

Background and objectives: Leinen, Rea

Operations: Leinen, Rea

Lithology: Erzinger, Kastner, Lyle, Owen

Biostratigraphy: Knüttel, Romine

Sedimentation rates: Romine, Knüttel

Physical properties: Becker

Igneous petrology: Goldfarb, Pearce

Interstitial and formation waters: Boulègue, Gieskes

Paleomagnetism: Nishitani

Heat flow: Hobart

Downhole measurements: Anderson, Hobart, Moos, Newmark

Borehole seismology (Hole 504B): Stephen

Summary and conclusions: Leinen, Rea

\section{EXPLANATORY NOTES}

Core description forms are presented in this volume to aid investigators in selecting samples for detailed study. Those who desire to obtain samples should refer to the Sample Distribution Policy at the front of this volume. Sample request forms may be obtained from The Curator, Ocean Drilling Program, Texas A\&M University, College Station, TX 77843-3469. Requests must be as specific as possible: include hole, core, section, interval within a section, and volume of sample required. This section of this chapter explains the terminology, labeling, and numbering conventions used by DSDP, describes the sediment classification and biostratigraphic framework in use, and presents the preliminary lithologic and paleontologic data on core forms as a guide in sampling. However, the investigator should be aware that the data on the core description forms are subject to revision.

\section{Numbering of Sites, Holes, Cores, and Samples}

DSDP drill sites are numbered consecutively from the first site drilled by the Glomar Challenger in 1968. Site numbers are slightly different from hole numbers. A site number refers to one or more holes drilled while the ship was positioned over one acoustic beacon. These holes may be located within a radius as great as $900 \mathrm{~m}$ from the beacon. Several holes may be drilled at a single site by pulling the drill pipe above the seafloor (out of one hole), moving the ship $100 \mathrm{~m}$ or more from the previous hole, and then drilling another hole.

The first (or only) hole drilled at a site takes the site number. A letter suffix distinguishes each additional hole at the same site. In other words, the first hole takes the site number, the second takes the site number with suffix A, the third takes the site number with suffix B, and so forth. It is important, for sampling purposes, to distinguish between the holes drilled at a site, because at a given depth in different holes the sediments or rocks recovered usually come from different positions in the stratigraphic column. 
Two types of coring systems are used on the Glomar Challenger: standard rotary coring, which cuts cores $\approx 9.5 \mathrm{~m}$ long and has been used since Leg 1 ; and hydraulic piston coring, which has been used since Leg 64 . No special numbering is used to identify holes cored with the hydraulic piston corer (HPC). The HPC operates by lowering a core barrel inside the drill string and hydraulically ejecting the core barrel into the sediment. After the core barrel is retrieved, the pipe is lowered to the next interval and the procedure is repeated. Disturbance is common in the top 50 to $100 \mathrm{~cm}$ of HPC cores, especially near the top of a hole. However, the standard rotary coring system typically disturbs the cores in the upper $100 \mathrm{~m}$ of any hole, and generally half or more of each core is quite disturbed.

The cored interval is measured in meters below seafloor. The depth interval of an individual core is the depth below seafloor at which the coring operation began to the depth at which the coring operation ended. With rotary coring, the coring interval is generally $9.5 \mathrm{~m}$, the nominal length of a core barrel; however, the coring interval may be shorter or (rarely) longer. Cored intervals are not necessarily adjacent to one another; they may be separated by drilled intervals. In soft sediment, the drill string can be washed ahead with the core barrel in place, but not recovering sediment, by pumping water down the pipe at high pressure to wash the sediment out of the way of the bit and up the space between the drill pipe and the wall of the hole; however, if thin, hard rock layers are present within the washed interval, pieces of these resistant layers may be caught in the core barrel. Since these pieces are from the washed interval, the cored interval is greater than $9.5 \mathrm{~m}$. In drilling hard rock, in order to prevent recovery, the core barrel may be replaced by a center bit.

Cores taken from a hole are numbered serially from the top of the hole downward. Core numbers and the associated cored interval in meters below seafloor are normally unique in a given hole, although if an interval is cored twice, the second core for the interval is given the same number as the first with a suffix, such as $\mathrm{S}$ for supplementary. ( $\mathrm{S}$ is also used as a prefix to the core number for sidewall core samples.) With rotary coring, full recovery for a single core is normally $9.28 \mathrm{~m}$ of sediment or rock in a plastic liner (6.6 cm inner diameter) plus about $0.2 \mathrm{~m}$ of sediment or rock without a plastic liner in the core-catcher. The core-catcher is a device at the bottom of the core barrel that prevents the cored sample from sliding out when the barrel is being retrieved from the hole. The part of the core in the plastic liner is then cut into $1.5-\mathrm{m}$ sections and numbered serially from the top of the core (Fig. 4). When recovery is full, the sections are numbered from 1 to 7 (the last section is shorter than $1.5 \mathrm{~m}$ ). The core-catcher sample is placed below the last section when the core is described and is labeled CC (core-catcher); it is treated as a separate section.

This numbering technique differs from that used from Legs 1 to 45 , which designated the top section 0 . Thus, from Legs 1 to 45 the seven sections were labeled $0,1,2$, $3,4,5$, and 6 . In the system used from Leg 46 to the present, the seven sections are labeled $1,2,3,4,5,6$, and 7 .

If recovery is less than 100 percent, the top of the recovered sediment is placed at the top of the cored interval before the $1.5-\mathrm{m}$ sections are numbered (Fig. 4). We use this convention for convenience in data handling and consistency, since we do not know the sediment's true stratigraphic position within the cored interval. As many sections will be numbered as are needed to accommodate the length of the core recovered. For example, $3 \mathrm{~m}$ of core sample in plastic liners will be divided into two $1.5-\mathrm{m}$ sections. Sections are cut by starting at the top of the recovered sediment, so the last section may be shorter than $1.5 \mathrm{~m}$.

If, with less than 100 percent recovery, the core fragments are separated and the shipboard scientists believe the sediment is not contiguous, the voids between the sections are retained as is when the sections are measured and numbered. Voids are usually labeled as such in the core description forms (Fig. 4). In the core description forms, the core-catcher sample appears below the lowest section of core.

Samples are designated by the distance in centimeters from the top of each section to the top and bottom of the sample. A full identification number for a sample consists of leg, site, hole, core, and interval in centimeters from the top of the section. For example, a sample identification number of $75-531 \mathrm{~A}-6-3,12-14 \mathrm{~cm}$ would be interpreted as the sample taken 12 to $14 \mathrm{~cm}$ from the top of Section 3 of Core 6, from the second hole drilled at Site 531 during Leg $75 .{ }^{3}$ A sample from the corecatcher of this core would be designated $75-531 \mathrm{~A}-6, \mathrm{CC}$, $12-14 \mathrm{~cm}$.

The depth below seafloor for a sample numbered $75-531 \mathrm{~A}-6-3,12-14 \mathrm{~cm}$ would be the sum of the depth to the top of the cored interval for Core 6 (let us say $430 \mathrm{~m}) ; 3 \mathrm{~m}$ for Sections 1 and 2 (1.5 m each); and $12 \mathrm{~cm}$ (the depth below the top of Section 3 ). The result, which is the sample depth below seafloor, is $433.12 \mathrm{~m}$. (Sample requests should specify the centimeter interval within the core and section instead of depth below seafloor, however.)

\section{Handling of Cores Containing Sediments}

A core containing sediments is normally cut into $1.5-\mathrm{m}$ sections, sealed, and labeled. The sections are then taken into the core laboratory, where gas analyses and continuous wet-bulk-density determinations using the Gamma Ray Attenuation Porosity Evaluator (GRAPE; see Boyce, 1976) are made.

The cores are then split longitudinally into working and archive halves. Samples are extracted from the working half, including those used to determine grain-size distribution, mineralogy (by X-ray diffraction), sonic velocity (by the Hamilton Frame method as described in Boyce, 1976), wet-bulk density (by a static GRAPE technique; Boyce, 1976), water content (by gravimetric analysis), carbon-carbonate content, calcium carbonate con-

\footnotetext{
${ }^{3}$ This sample is hypothetical; only one core was actually recovered from Hole 531A.
} 

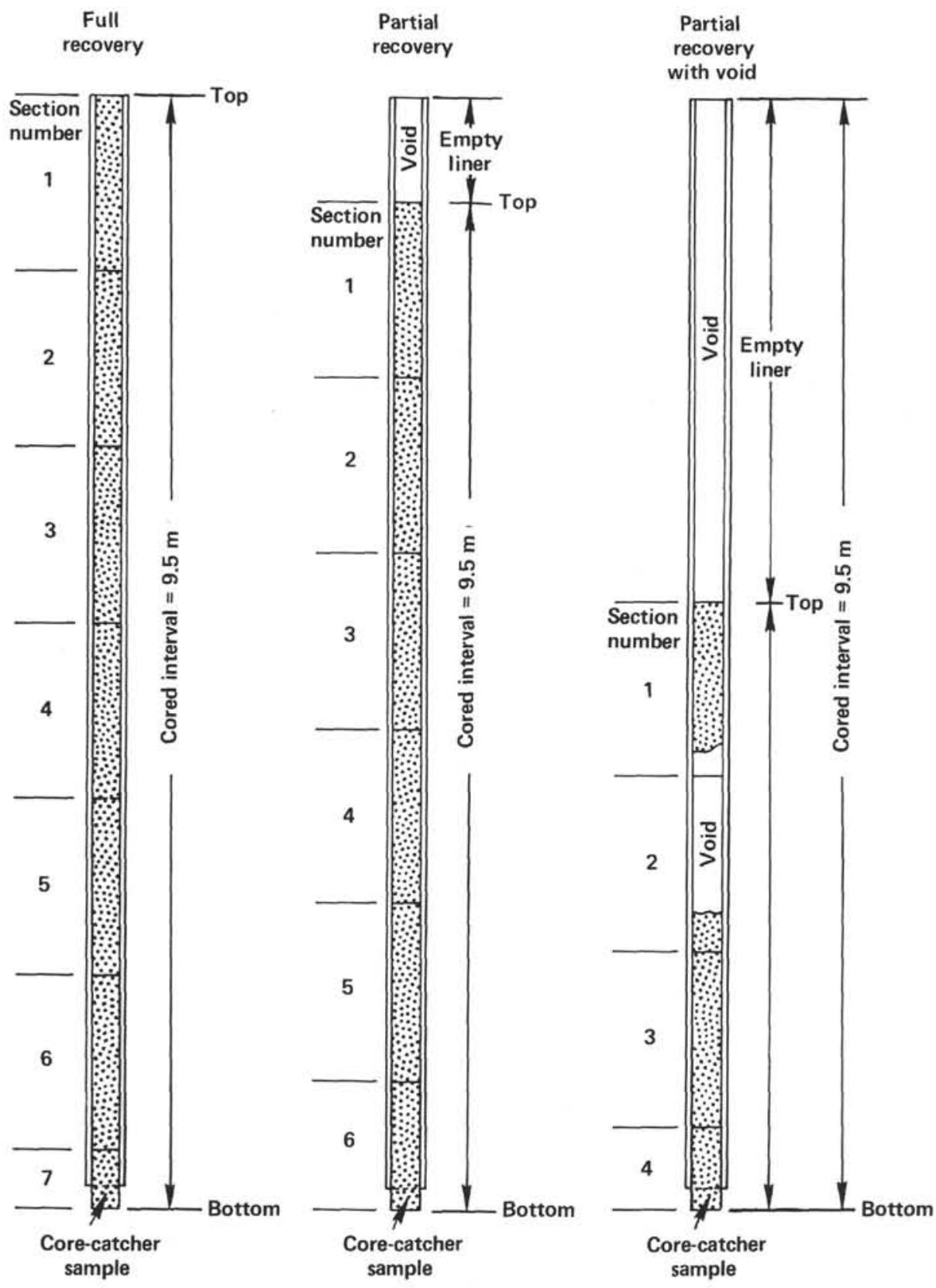

Figure 4. Core cutting and labeling procedure.

tent (by carbonate bomb), geochemistry, paleontology, and so forth.

Smear slides or thin sections are prepared from each major lithology and most minor lithologies and examined under the microscope. The archive half is then described on core description forms and photographed. Physical disturbance by the drill bit, color, texture (for uncemented lithologies), sedimentary and igneous structures, and the composition $( \pm 20 \%)$ of the various lithologies are noted on the core description forms.

After the cores are sampled and described, they are kept in cold storage on board the Glomar Challenger until they can be transferred to a DSDP repository. Sections of core removed for the study of organic geochemistry are frozen immediately on board ship and kept frozen. Frozen cores are presently being stored at the DSDP
West Coast Repository (Scripps Institution of Oceanography).

The data in the core description forms (smear slide description, plus occasional peels and thin sections; percent $\mathrm{CaCO}_{3}$; and so on) were all determined on board ship. The position of the samples used to acquire these data is shown by symbols in the core description forms. These and the other symbols used in the forms are defined in Figures 5 to 9 .

\section{Special Cores and Samples}

Occasionally, special cores or samples are recovered that require specific identification. These are given the following prefixes:

$\mathrm{X}-$ miscellaneous debris or out-of-sequence core material. 
C-center bit samples; that is, samples obtained upon removal of the center bit (a device used, albeit sometimes unsuccessfully, to prevent core recovery while drilling or washing ahead for some interval).

$\mathrm{S}$-sidewall core; that is, a core taken in the side of the hole, usually to obtain a sample of material not recovered during previous coring.

$\mathrm{H}$-wash core; that is, a core taken while washing ahead for an interval larger than $9.5 \mathrm{~m}$ (say, $50 \mathrm{~m}$ ), but without the center bit in place. Such a core may sample at several places in the washed interval, but the depths within the interval cannot be specified.

B-bit material; that is, material removed from a core bit when the drill string is retrieved after a hole is completed or before the hole is re-entered with a new core bit.

Cores or samples of these types are designed X1, X2, $\mathrm{H} 1, \mathrm{H} 2$, and so forth. The numbering of each sequence is independent, and the numbering follows the sequence in which the cores or samples were obtained. Additional designations for special samples may be assigned by the shipboard party or cruise operations manager. The letter designation for these samples is chosen in consultation with the DSDP curatorial representative and laboratory officer, and is indicated on each core description form.

\section{Description and Classification of Sediments}

The sediment description and classification scheme used on Leg 92 was that devised by the JOIDES Sedimentary Petrology and Physical Properties Panel and approved by the JOIDES Planning Committee in March of 1974. This classification system is given verbatim below.

\section{CLASSIFICATION OF SEDIMENTS}

Several lithologic classifications designed for the construction of the several graphic core and hole summaries have been used during the lifetime of the Deep Sea Drilling Project. The classification system described here has been devised by the JOIDES Panel on Sedimentary Petrology and Physical Properties and adopted for use by the JOIDES Planning Committee in March 1974.

\section{Principles Used in Classification}

1. This is a lithologic summary classification designed to generalize core descriptive material of greater detail into a form suitable for standard core and hole logs. Its systematic use will facilitate core to core and leg to leg comparisons.

2. The classification covers most of the lithologic types encountered so far but does not attempt to be comprehensive. A category "Special Rock Types" shows additional definitions and terminology at the discretion of the shipboard staff for rock types not covered.

3. Sediment names are those in common usage and have been defined within the limits of existing definitions.

4. Categories are based on sediment parameters measured on board ship. Refinement by shore laboratory data is possible but not necessary.

5. The classification is descriptive and genetic implications are not intended.

6. The degree of detail of the classification is scaled to the space limitations of printed graphic hole and core summaries.

\section{Shipboard Parameters Measured}

Sediment and rock names are defined solely on the basis of compositional and textural parameters. The compositional factors are most important for description of those deposits more characteristic of open marine conditions, with textural factors becoming more important for the classification of hemipelagic and near-shore facies. Sediment names are thus based solely upon these parameters as determined in smear slides aided by compositional and textural properties apparent to the naked eye or under the hand lens. Other descriptive parameters include: induration, sediment disturbance, sedimentary structures, and color. The determination of these parameters is as follows:

1) Composition-biogenic and mineral components are estimated in percent from smear slides. $\mathrm{CaCO}_{3}$ content is estimated by using the carbonate bomb available on the ship. Even with rapid use, a value to $\pm 5 \%$ is achievable.

2) Texture-visual estimates from smear slide examination.

3) Induration-The determination of induration is highly subjective, but field geologists have successfully made similar distinctions for many years. The categories suggested here are thought to be practical and significant. The criteria of Moberly and Heath (1971) are used for calcareous deposits; subjective estimate or behavior in core cutting for others. There are three classes for calcareous sediments; two for all others.

a) Calcareous sediments

(i) Soft: Oozes have little strength and are readily deformed under the finger or the broad blade of a spatula.

(ii) Firm: Chalks are partly indurated oozes: they are friable limestones that are readily deformed under the fingernail or the edge of a spatula blade. More indurated chalks are termed limestones (see below).

(iii) Hard: Limestones as a term should be restricted to cemented rocks.

b) The following criteria are recommended for all but calcareous sediments:

(i) If the material is low state of induration as to allow the core to be split with a wire cutter, the sediment name only is used (e.g., silty clay: mud).

(ii) If the core must be cut on the band saw or diamond saw, the suffix 'stone' is used (e.g., silty claystone: mudstone; or shale, if fissile.)

4) Sediment Disturbance-Deformational structures are generally of the type found in piston cores, and are usually simple to visualize and interpret.

a) Soft to firm sediment: The following categories are recommended.

(i) Slightly deformed-bedding contacts are slightly bent.

(ii) Moderately deformed-bedding contacts have undergone extreme bowing.

(iii) Very deformed-bedding is completely disturbed, sometimes showing symmetrical diapir-like structure.

(iv) Soupy-water saturated intervals which have lost all aspects of original bedding.

b) Hard sediments: There is also the need to indicate the degree of fracturing in hard sediments/rock. This is best accomplished with a written description in the Lithologic Description portion of the Core Form (Fig. 5).

c) Drilling "biscuits"-semi-indurated sediments are broken into flat $3-5 \mathrm{~cm}$ or so "biscuits" which internally are undeformed, but were rotated against each other resulting in lenses of soft, intensely deformed mud or ooze in between. Description of this is also best accomplished using the Lithologic Description portion of the Core Form (Fig. 5).

5) Sedimentary structures-in many cores it is extremely difficult to differentiate between natural and coring-induced structures. Consequently, the description of sedimentary structures is optional. The following approach is suggested as a guideline, but the specialist is encouraged to use his own preferred system and set of symbols.

a) Median grain size profile: For the sections of terrigenous sediments, with interbeds of varying textural characteristics, the construction of median grain size profile based on hand lens observations provides a rapid method for illustrating graded and non-graded beds, bed thickness, and size distribution. 
\begin{tabular}{l|l|l|l|l}
\multicolumn{1}{l}{ SITE } & \multicolumn{2}{c}{ COLE CORED INTERVAL (meters below the sea floor) } \\
\hline & 0 & 0 & &
\end{tabular}

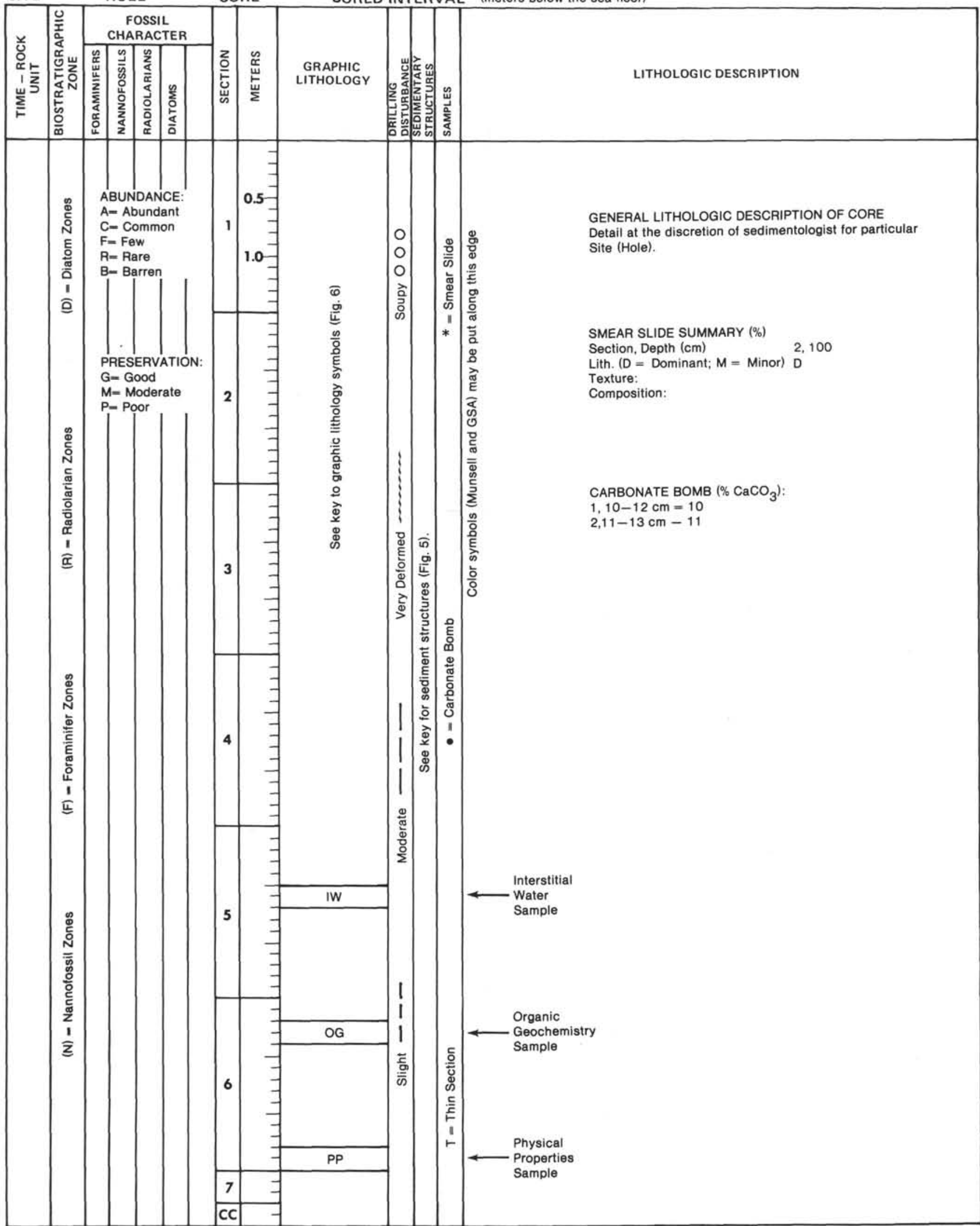

Figure 5. Typical sedimentary core description form, showing symbols used for sediment deformation, codes used for sample type, and other general information. 
b) Sedimentary structures: A set of suggested symbols is provided for categories shown on Figure 6.

6) Color-According to standard Munsell and GSA color charts.

\section{Use of the Core Form}

1) Mandatory Graphic Lithology Column-This graphic column is based on the above classification scheme. Completion of the column using the appropriate symbols (Fig. 7) must be done for each site, and will be included in the Initial Core Description (ICD) and Initial Report Volume. The "Special Rock Type" category should be used for sediment types not in the classification.

a) Optional graphic column: If circumstances or the special skills and interests of the shipboard staff indicate an additional modified or different classification, another

\begin{tabular}{|c|c|}
\hline 1 & Primary structures \\
\hline & Interval over which primary sedimentary structures occur \\
\hline$m$ & Current ripples \\
\hline$\mu$ & Micro-cross laminae (including climbing ripples) \\
\hline & Parallel laminae \\
\hline$w w$ & Wavy bedding \\
\hline & Flaser bedding \\
\hline$P$ & Lenticular bedding \\
\hline & Slump blocks or slump folds \\
\hline & Load casts \\
\hline 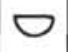 & Scour \\
\hline$\bullet \bullet \bullet$ & Graded bedding (normal) \\
\hline 00 & Graded bedding (reversed) \\
\hline ST & Convolute and contorted bedding \\
\hline 17 & Water escape pipes \\
\hline M & Mud cracks \\
\hline ZI & Cross-stratification \\
\hline & Sharp contact \\
\hline & Scoured, sharp contact \\
\hline & Gradational contact \\
\hline 2 & Imbrication \\
\hline & Fining-upward sequence \\
\hline$v$ & Coarsening-upward sequence \\
\hline 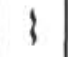 & Bioturbation - minor ( $30 \%$ surface area) \\
\hline 《I & Bioturbation - moderate (30-60\% surface area) \\
\hline 级 & Bioturbation - strong (more than $60 \%$ surface area) \\
\hline & Secondary structures \\
\hline ○ & Concretions \\
\hline & Compositional symbols \\
\hline (๐) & Fossils in general (megafossils) \\
\hline$\widehat{O}$ & Shells (complete) \\
\hline$\varnothing$ & Shell fragments \\
\hline$Q$ & Wood fragments \\
\hline
\end{tabular}

Figure 6. Symbols used to show sediment structure. graphic column may be added to the right of the Mandatory Column using definitions, terminology and symbols that, in the opinion of the shipboard staff, will increase the information yield. This Optional Column must not substitute for the Mandatory Column.

2) Sediment disturbance column-Completion of the sediment disturbance column using symbols and distinctions given below is mandatory.

3) Sedimentary structure columns-Structures may be designated on the core form in the sedimentary structure column parallel to the sediment disturbance column, and/or on the median grain size profile (for the sections of terrigenous sediments, with interbeds of varying textural characteristics). The median grain size profile is located in the lithologic description portion of the core form. A set of suggested symbols for a few more common structures has been prepared by DSDP (Fig. 6), but the shipboard geologist is free to use whatever additional symbols he may wish. These optional columns may not substitute for the mandatory sediment disturbance column and must be distinct from it.

4) Lithologic description column-Format, style, and terminology of the descriptive portion of the core sheets are not controlled by the mandatory column scheme, beyond the minimal name assignment which should be derived from this classification. However, colors and additional information on structure and textures should normally be included in the textural section of the core description.

\section{Lithologic Classification Scheme}

The following define compositional class boundaries and use of qualifiers in the lithologic classification scheme:

1) Compositional Class Boundaries

a) $\mathrm{CaCO}_{3}$ content (determined by $\mathrm{CaCO}_{3}$ bomb): $30 \%$ and $60 \%$. With a $5 \%$ precision and given the natural frequency distribution of $\mathrm{CaCO}_{3}$ contents in oceanic sediments, these boundaries can be reasonably ascertained.

b) Biogenic opal abundance (expressed as percent siliceous skeletal remains in smear slides): $10 \%, 30 \%$, and $50 \%$. Smear-slide estimates of identifiable siliceous skeletal material generally imply a significantly higher total opal abundance. The boundaries have been set to take this into account.

c) Abundance of authigenic components (zeolites, Fe, and Mn micronodules etc), fish bones, and other indicators of very slow sedimentation (estimated in smear slides); semiquantitative boundary: common $10 \%$. These components are quite conspicuous and a semiquantitative estimate is adequate. Even a minor influx of calcareous, siliceous, or terrigenous material will, because of the large difference in sedimentation rate, dilute them to insignificance.

d) Abundance of terrigenous detrital material (estimated from smear slides): $30 \%$

e) Qualifiers: Numerous qualifiers are suggested; the options should be used freely. However, components of less than $5 \%$ (in smear slide) should not be used as a qualifier except in special cases. The most important component should be the last qualifier. No more than two qualifiers should be used.

\section{Description of Sediment Types}

1) Pelagic clay-principally authigenic pelagic deposits that accumulate at very slow rates. The class is often termed brown clay, or red clay, but since these terms are confusing, they are not recommended.

a) Boundary with terrigenous sediments: Where authigenic components ( $\mathrm{Fe} / \mathrm{Mn}$ micronodules, zeolites), fish debris, etc., become common in smear slides. NOTE: Because of large discrepancy in accumulation rates, transitional deposits are exceptional.

b) Boundary with siliceous biogenic sediments: $<30 \%$ identifiable siliceous remains.

c) Boundary with calcareous biogenous sediments: Generally the sequence is one passing from pelagic clay through siliceous ooze to calcareous ooze, with one important exception: at the base of many oceanic sections, black, brown, or red clays occur directly on basalt, overlain by or grading up into calcareous sediments. Most of the ba- 


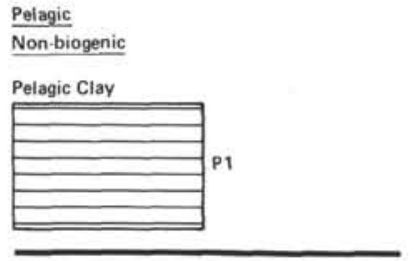

Siliceous Biogenic

Pelagic Siliceous Biogenic - Soft

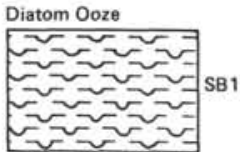

Pelagic Siliceous Biogenic - Hard

Diatomite

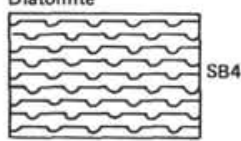

S84

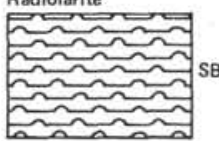

Transitional Siliceous Terrigenous Sediments

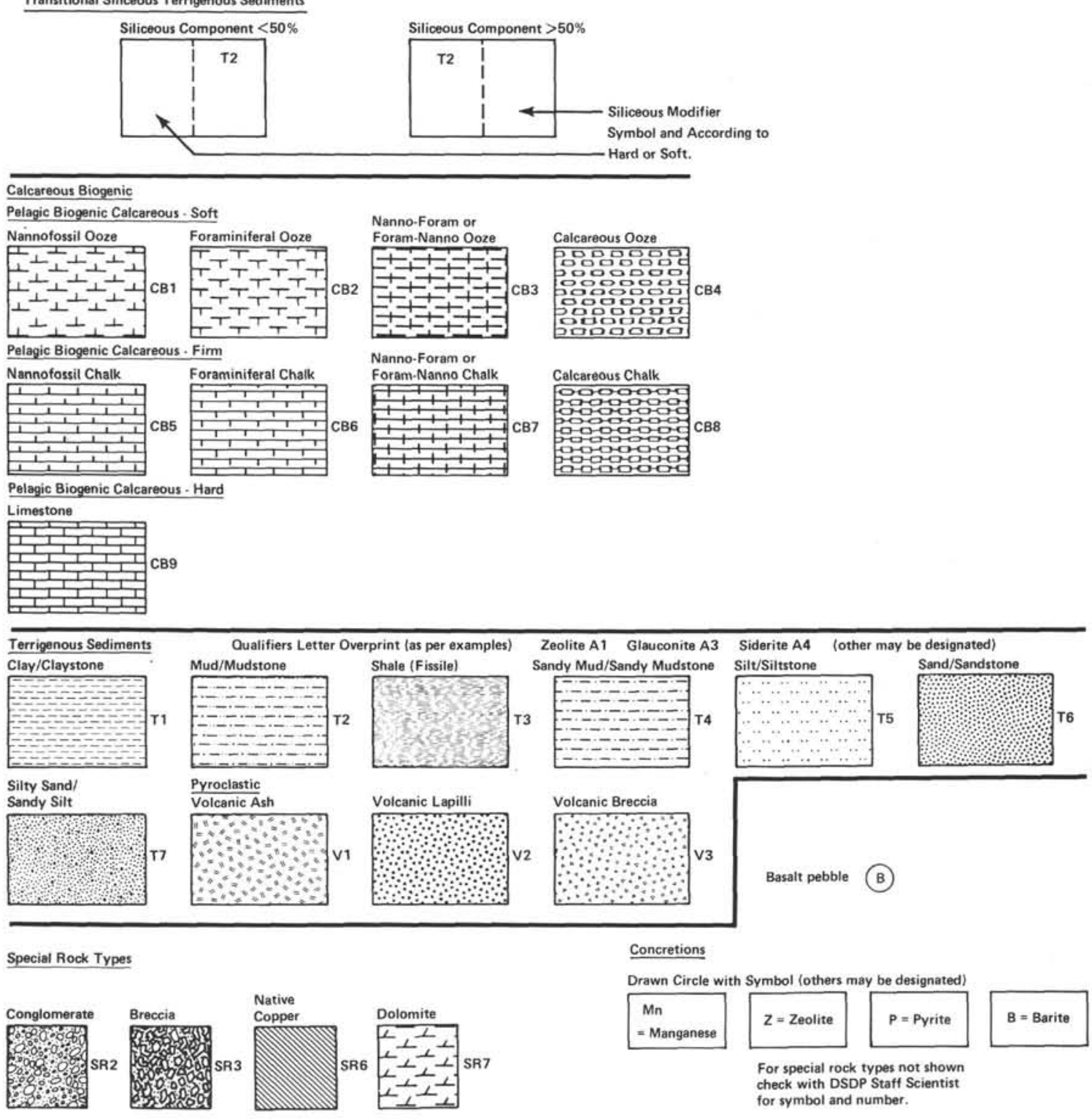

Vertical bar percent

(\%) Designation

for Graphic Log.

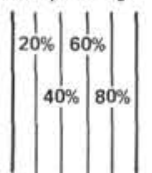

Diatom. Pad or

Siliceous Ooze

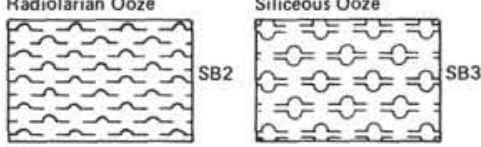

$\sim \Omega \sim=$

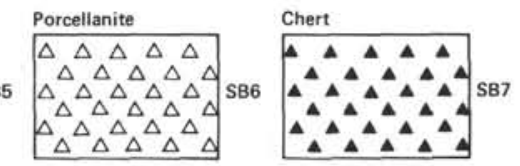

Figure 7. Symbols used to describe the lithology of sediment and sedimentary rocks after visual examination of the cores. 
sal clayey sediments are rich in iron, manganese and metallic trace elements. For proper identification they require more elaborate geochemical work than is available on board. These sediments are placed in the "Special Rock" category, but care should be taken to distinguish them from ordinary pelagic clays.

2) Pelagic siliceous biogenic sediments-These are distinguished from the previous category because they have more than $30 \%$ identifiable siliceous microfossils. They are distinguished from the following category by $\mathrm{CaCO}_{3}$ content of less than $30 \%$. There are two classes: Pelagic biogenic siliceous sediments (containing less than $30 \%$ silt and clay); and transitional biogenic siliceous sediments (containing more than $30 \%$ silt and clay and more than $10 \%$ diatoms).

a) Pelagic biogenic siliceous sediments:

soft: Siliceous ooze (radiolarian ooze, diatom ooze, depending on dominant component).

hard: radiolarite porcellanite

diatomite chert

(i) Qualifiers:

Radiolarians dominant: radiolarian ooze or radiolarite.

Diatoms dominant: diatom ooze or diatomite.

Where uncertain: siliceous (biogenic) ooze, or chert or porcellanite, when containing $>10 \% \mathrm{CaCO}_{3}$, qualifiers are as follows: indeterminate carbonate: calcareous--

or

nannofossils only:

foraminifers only:

nannofossil-. nannofossil-foraminifer-- depending on dominant

foraminiferal-nannofossil-component

b) Transitional biogenic siliceous sediments:

Diatoms $<50 \%$ diatomaceous mud: soft diatomaceous mudstone: hard

Diatoms $>50 \%$ muddy diatom ooze: soft muddy diatomite: hard

Radiolarian equivalents in this category are rare and can be specifically described.

3) Pelagic biogenous calcareous sediments-These are distinguished from the previous categories by a $\mathrm{CaCO}_{3}$ content in excess of $30 \%$. There are two classes: Pelagic biogenic calcareous sediments (containing less than $30 \%$ silt and clay); and transitional biogenic calcareous sediments (containing more than $30 \%$ silt and clay).

a) Pelagic biogenic calcareous sediments:

soft: calcareous ooze

firm: chalk

hard: indurated chalk

The term limestone should preferably be restricted to cemented rocks.

(i) Compositional Qualifiers $\leq-$

Principal components are: nannofossils and foraminifers.

One or two qualifiers may be used, for example:

$\begin{array}{cl}\begin{array}{cl}\text { Foram } \% \\ <10\end{array} & \begin{array}{l}\text { Nannofossil ooze, chalk, } \\ \text { limestone }\end{array} \\ 10-25 & \begin{array}{l}\text { Foraminiferal-nannofossil } \\ \text { ooze }\end{array} \\ 25-50 & \text { Nannofossil-foraminifer ooze } \\ >50 \text { for: } & \text { Foraminifer ooze }\end{array}$

Calcareous sediment containing more than 10-20\% identifiable siliceous fossils carry the qualifier radiolarian, diatomaceous, or siliceous depending on the quality of the identification. For example, radiolarian-foraminifer ooze.

b) Transitional biogenic calcareous sediments

(i) $\mathrm{CaCO}_{3}=30-60 \%$ : marly calcareous pelagic sediments

soft: marly calcareous (or nannofossil, foraminifer, etc.), ooze (see below)

firm: marly chalk

hard: marly limestone (ii) $\mathrm{CaCO}_{3}>60 \%$ : Calcareous pelagic sediments. soft: calcareous (or nannofossil, foraminifer, etc.), ooze (see below)

firm: chalk

hard: limestone

NOTE: Sediments containing $10-30 \% \mathrm{CaCO}_{3}$ fall in other classes where they are denoted with the adjective "calcareous." Less than $10 \%$ $\mathrm{CaCO}_{3}$ is ignored.

4) Terrigenous sediments

a) Sediments falling in this portion of the classification scheme are subdivided into textural groups on the basis of the relative proportions of three grain size constituents, i.e., clay, silt, and sand. Rocks coarser than sand size are treated as "Special Rock Types." The size limits for these constituents are those defined by Wentworth (1922) (Fig. 8).

Five major textural groups are recognized on the accompanying triangular diagram (Fig. 9). These groups are defined according to the abundance of clay $(>90 \%$, $90-10 \%,<10 \%)$ and the ratio of sand to silt $(>1$ or $<1)$. The terms clay, mud, sandy mud, silt, and sand are used for the soft or unconsolidated sediments which are cut with a wire in the shipboard core splitting process. The hard or unconsolidated equivalents for the same textural groups are claystone, mudstone (or shale, if fissile), sandy mudstone, siltstone, and sandstone. Sedimentary rocks falling into the consolidated category include those which must generally be cut with the band saw or diamond saw. Sands and sandstones may be subdivided further into very fine-, fine-, medium-, coarse-, or very coarse-grained sands and sandstones according to their median grain size.

(i) Qualifiers-In this group numerous qualifiers are possible, usually based on minor constituents, for example: glauconite, pyritic, feldspathic. In the sand and sandstone category, conventional divisions such as arkose, graywacke, etc., are, of course, acceptable, providing the scheme is prop-

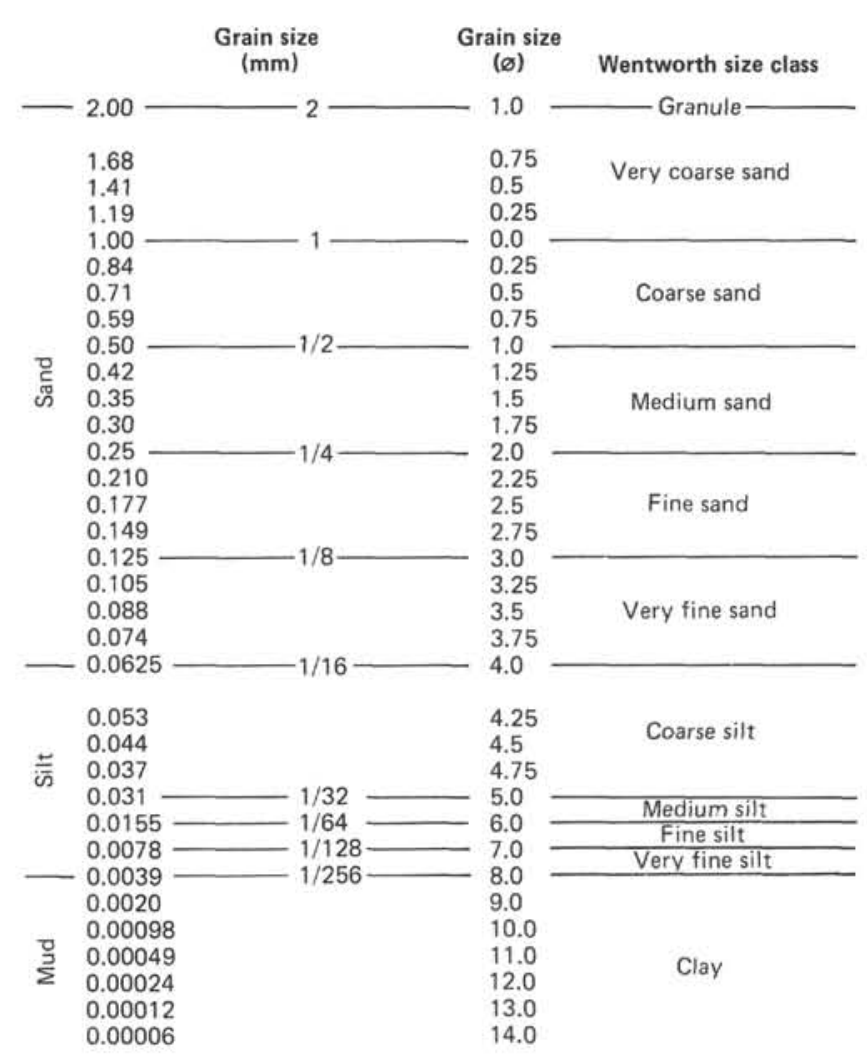

Figure 8. Grade scales for terrigenous sediments. 


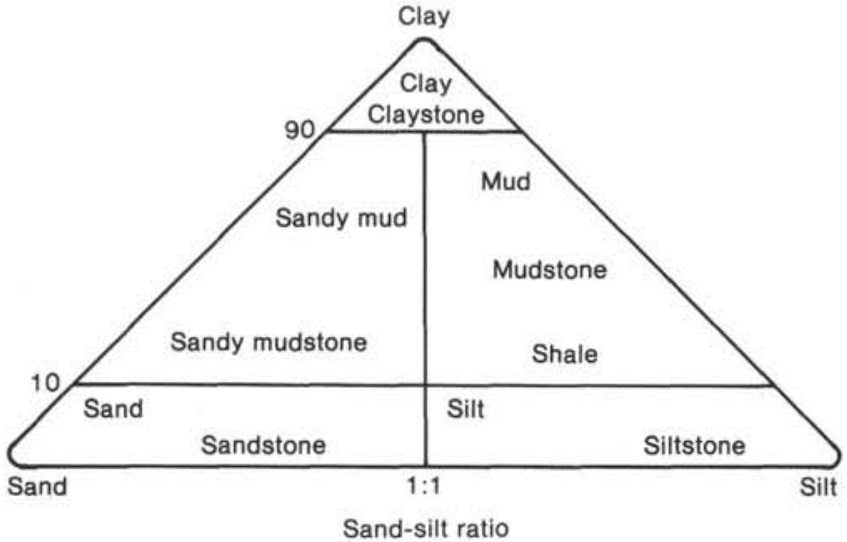

Figure 9. Class boundaries for terrigenous sediments.

b)

erly identified. Clays, muds, silts, and sands containing $10-30 \% \mathrm{CaCO}_{3}$ shall be called calcareous. Volcanogenic sediments

Pyroclastic rocks are described according to the textural and compositional scheme of Wentworth and Williams (1932). The textural groups are:

Volcanic breccia $>32 \mathrm{~mm}$

Volcanic lapilli $\quad<32 \mathrm{~mm}$

Volcanic ash (tuff, indurated) $<4 \mathrm{~mm}$

Compositionally, these pyroclastic rocks are described as vitric (glass), crystal or lithic.

c) Clastic sediments of volcanic provenance are described in the same fashion as the terrigenous sediments, noting the dominant composition of the volcanic grains where possible.

5) Special rock types-The definition and nomenclature of sediment and rock types not included in the system described above are left to the discretion of shipboard scientists with the recommendation that they adhere as closely as practical to conventional terminology.

In this category fall such rocks as:

Intrusive and extrusive igneous rocks;

Evaporites, halite, anhydrite, gypsum (as a rock), etc.;

Shallow water limestone (biostromal, biohermal, coquina, oolite, etc.);

Dolomite;

Gravels, conglomerates, breccias;

Metalliferous brown clays;

Concretions, barite, iron-manganese, phosphorite, pyrite, etc.;

Coal, asphalt, etc.;

and many others.

The mandatory graphic lithology column should be completed by shipboard staff with appropriate symbols for intervals containing special rock types. It is imperative that symbols and rock nomenclature be properly defined and described by shipboard staff.

\section{Basement Description Conventions}

\section{Core Forms}

Initial core description forms for igneous and metamorphic rocks are not the same as those used for sediments. The sediment barrel sheets are substantially those published in previous Initial Reports. Igneous rock representation on barrel sheets is too compressed to provide adequate information for potential sampling. Consequently, Visual Core Description forms, modified from those used on board ship, are used for more complete graphic representation. All shipboard data per $1.5-\mathrm{m}$ section of core are listed on the modified forms as well as summary hand-specimen and thin-section descriptions. The symbols and a number of format conventions for igneous rocks are presented in Figure 10.

Igneous and metamorphic rocks are split using a rock saw with a diamond blade into archive and working halves. The latter is described and sampled on board ship. In a typical igneous rock description form (Fig. 11), the left column is a visual representation of the working half using the symbols of Figure 10. Two closely spaced horizontal lines in this column indicate the location of styrofoam spacers taped between basalt pieces inside the liner. Each piece is numbered sequentially from the top of each section, beginning with the number 1 . Pieces are labeled on the rounded (not the sawed) surface. Pieces that could be fitted together before splitting are given the same number, but are consecutively lettered $(1 \mathrm{~A}, 1 \mathrm{~B}$, $1 C$, etc.). Spacers are placed between pieces with different number, but not between those with different letters and the same number. In general, addition of spacers represents a drilling gap (no recovery). However, in cores where recovery is high, it is impractical to use spacers. In these cases, drilling gaps are indicated only by a change in numbers. All pieces have orientation arrows pointing to the top of the section, both on archive and working halves, provided the original unsplit piece was cylindri$\mathrm{cal}$ in the liner and of greater length than the diameter of the liner. Special procedures are used to ensure that orientation is preserved through every step of the sawing and labeling process. All pieces suitable for sampling requiring knowledge of top from bottom are indicated by upward-pointing arrows to the left of the piece numbers on the description forms. Since the pieces are rotated during drilling, it is not possible to sample for declination studies.

Samples are taken for various measurements on board ship. The type of measurement and approximate location are indicated in the column headed "Shipboard Studies" using the following notation:

$\mathrm{X}$-X-ray fluorescence analysis

M-magnetics measurements

$\mathrm{S}-$ sonic velocity measurements

$\mathrm{T}$-thin section

D-density measurements

$\mathrm{P}$-porosity measurements

Up to seven such visual representations can be included on a single igneous rock description sheet (Fig. 12), which includes a summary core description and petrographic and analytical data.

\section{Igneous Rock Classification}

Igneous rocks are classified mainly on the basis of mineralogy and texture. Thin-section work in general adds little new information to the hand-specimen classification.

Basalts are termed aphyric, sparsely phyric, moderately phyric, or phyric, depending on the proportion of phenocrysts visible with the binocular microscope $(\approx \times 12)$. The basalts are called aphyric if phenocrysts are absent. For practical purposes, this means that if one piece of basalt is found with a phenocryst or two in a section where all other pieces lack phenocrysts, and no other 
Texture:

Used in graphic representation column

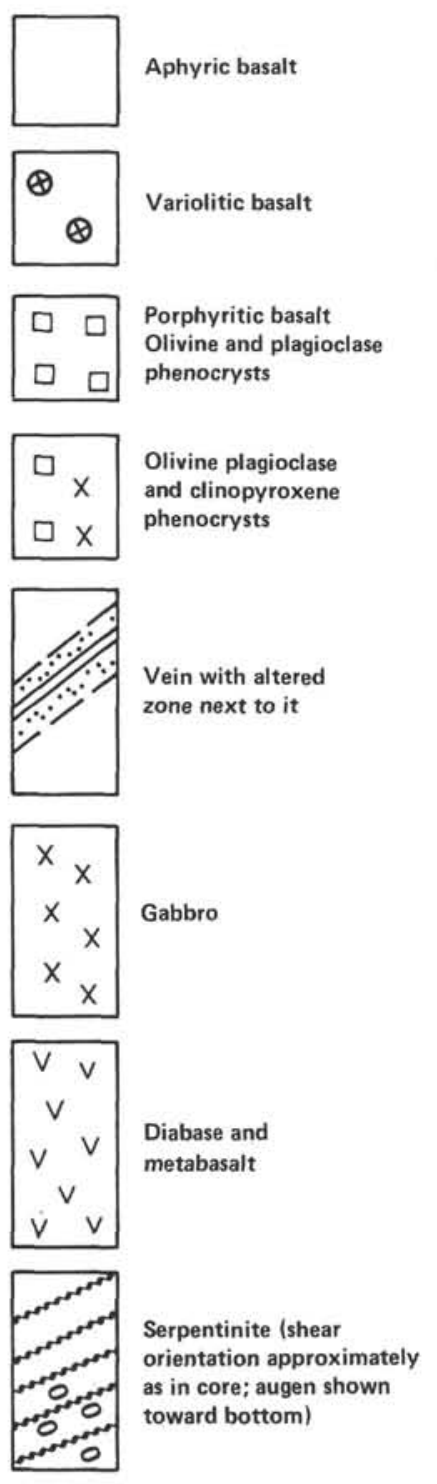

Weathering: alteration

Used in alteration column
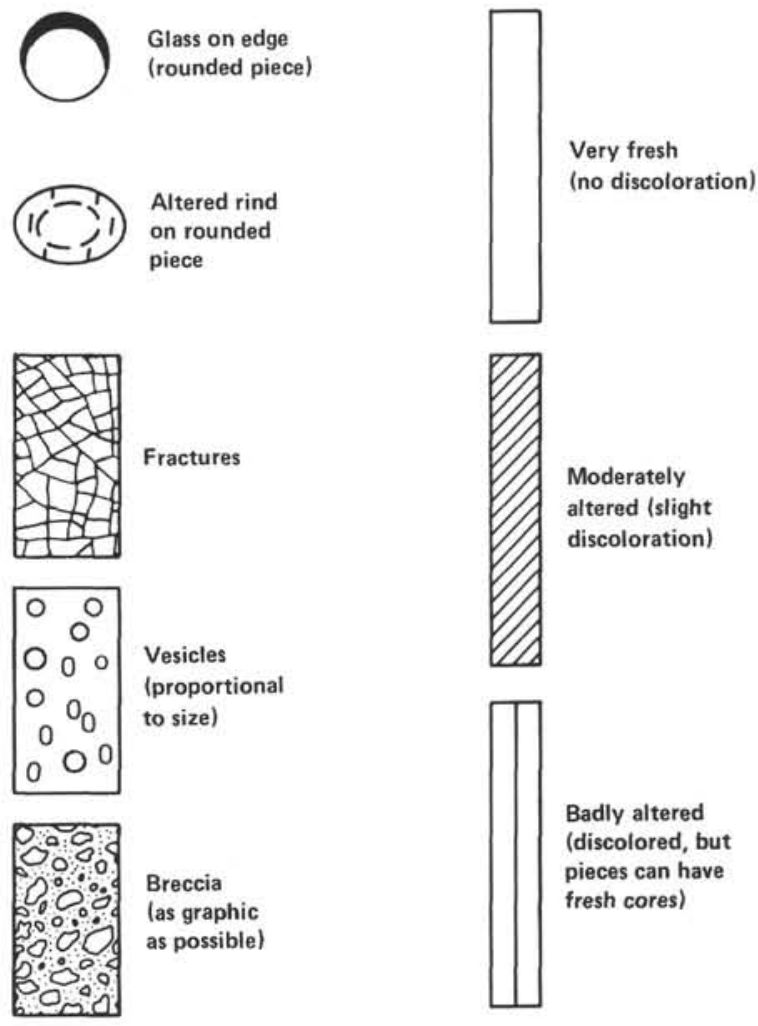

Local occurrences (indicate to right of alteration column):

$+=$ altered olivine phenocryst

0 = quart $z$ crystals

$C=$ calcite veins

= clay-filled vesicles

₹3 = calcite-filled vesicles

DISI = baked mudstone-chert selvage

$\mathrm{R}=$ red clays and/or iron hydroxides

$\mathrm{G}=$ green clays

$\mathrm{B}=$ blue green clays

$\mathrm{P}=$ pyrite or other metallic sulfides

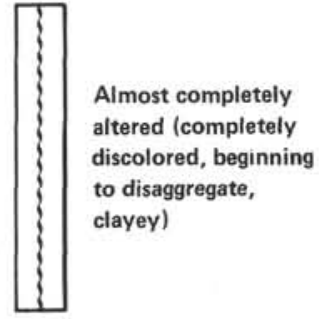

Almost completely altered (completely to disaggregate, clayey)

Figure 10. Symbols used to describe igneous rocks.

criteria such as grain size or texture distinguish this basalt from the others, it is described as aphyric. A note on the rare phenocrysts is included in the general description, however. This approach enables us to restrict the number of lithologic units to those that appear to be clearly distinct.

Sparsely phyric basalts are those in which phenocrysts make up 1 to $2 \%$ of almost every piece of a given core or section. Clearly contiguous pieces without phenocrysts are included in this category; again, the lack of phenocrysts is noted in the general description.

Moderately phyric basalts contain 2 to $10 \%$ phenocrysts. Aphyric basalts within a group of moderately phyric basalts are separately termed aphyric basalts.

Phyric basalts contain more than $10 \%$ phenocrysts. No separate designation is made for basalts with more than $20 \%$ phenocrysts; the proportion indicated in the core forms should be sufficient to guide the reader.
The basalts are further classified by phenocryst type, with phenocryst type preceding the terms phyric, sparsely phyric, and so forth. For example, a plagioclase-olivine moderately phyric basalt contains 2 to $10 \%$ phenocrysts, most of them plagioclase, but with some olivine.

Other rock types that are less commonly recovered, such as gabbro, serpentinite, andesites, granite, or metamorphic rocks, are classified according to such standard references as Williams et al. (1954) and Moorhouse (1959).

\section{BIOSTRATIGRAPHY AND TIME SCALES}

The biostratigraphy of sediments recovered during Leg 92 is based primarily upon the calcareous nannofossils. The zonation scheme used (Fig. 13) is that of Okada and Bukry (1980); the ages of the zone boundaries are from Haq (1984). Foraminifers were also used for stratigraphic purposes; those zonations are from Srinivasan 

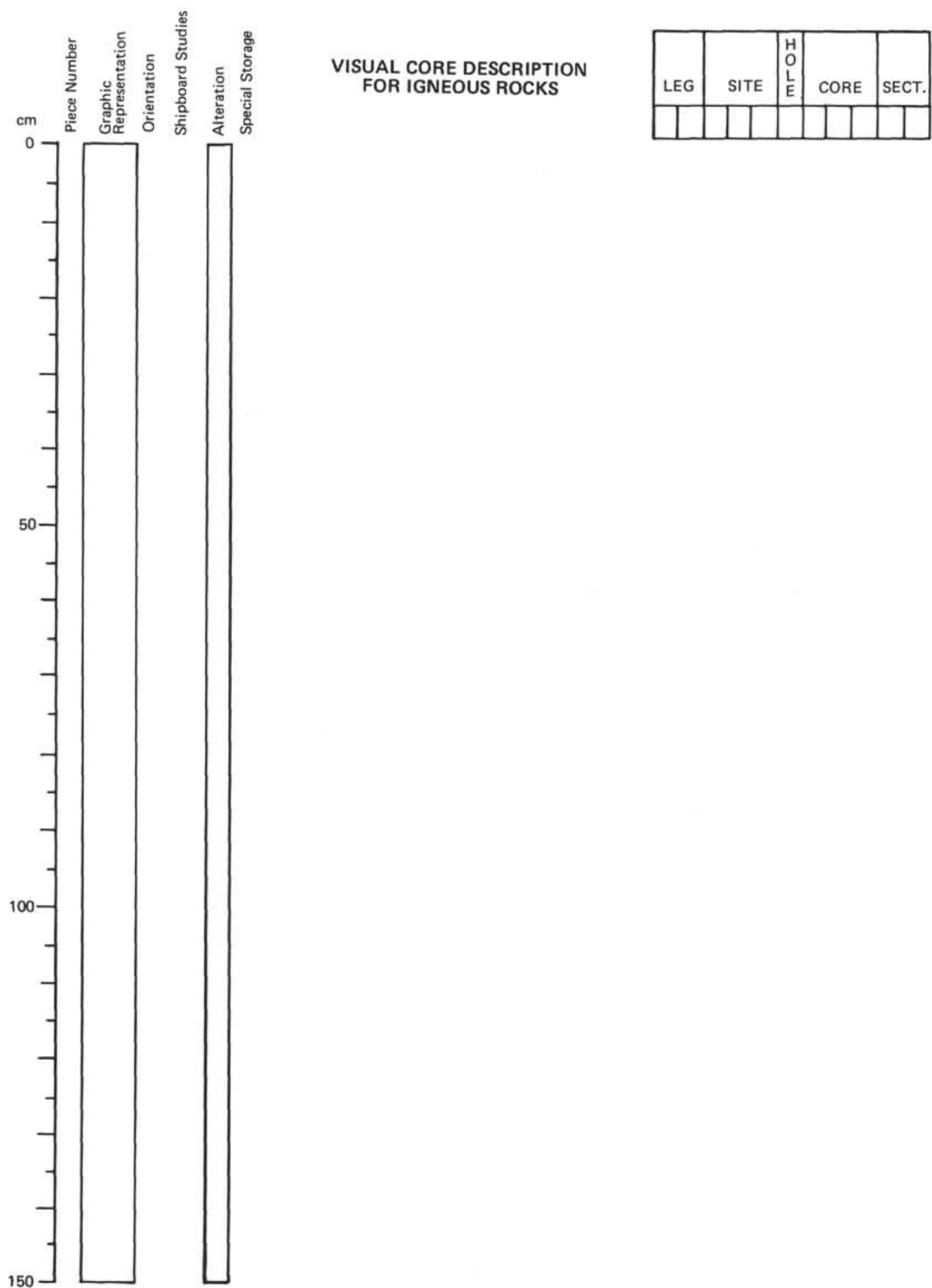

Figure 11. Igneous rock description form.

and Kennett (1981) and Kennett and Srinivasan (1983) for tropical and subtropical Pacific assemblages (Fig. 14). The Leg 92 scientists were aware of the ongoing revisions of the biostratigraphic chronologies being conducted by Berggren and coworkers (Berggren et al., 1985), but the requirement for consistency of Leg 92 efforts dictated that we adopt extant (in 1983) zonations, even knowing that they would change.
The magnetic reversal time scale, which was used to determine seafloor spreading rates and basement ages from magnetic anomalies, is that of Harland et al. (1982).

\section{REFERENCES}

Berggren, W., Kent, D. V., Flynn, J. J., and Van Couvering, J. A., 1985. Cenozoic geochronology. Geol. Soc. Am. Bull., 96:14071418. 
Boyce, R. E., 1976. Definitions and laboratory techniques of compressional sound velocity parameters and wet-water content, wetbulk density, and porosity parameters by gravimetric and gamma ray attenuation techniques. In Schlanger, S. D., Jackson, E. D., et al., Init. Repts. DSDP, 33: Washington (U.S. Govt. Printing Office), 931-958.

Bukry, D., 1973. Low-latitude coccolith biostratigraphic zonation. In Edgar, N. T., Saunders, J. B., et al., Init. Repts. DSDP, 15: Washington (U.S. Govt. Printing Office), 685-703.

Haq, B. U., 1984. Jurassic to Recent nannofossil biochronology: an update. In Haq, B. U. (Ed.), Nannofossil Biostratigraphy. Benchmark Pap. Geology 78: Hutchinson Ross Publ. Co. (Stroudsburg, PA), pp. 358-278.

Harland, W. B., Cox, A. V., Llewellyn, P. G., Pickton, C. A. G., Smith, A. G., and Walters, R., 1982. A Geologic Time Scale: Cambridge (Cambridge Univ. Press).

Kennett, J. P., and Srinivasan, M. S., 1983. Neogene Planktonic Foraminifers: Stroudsburg, PA (Hutchinson Ross Publ. Co.).

Moberly, R., Jr., and Heath, G. R., 1971. Carbonate sedimentary rocks from the western Pacific: Leg 7, Deep Sea Drilling Project. In Winterer, E. L., Riedel, W. R., et al., Init. Repts. DSDP, 7, Pt. 2: Washington (U.S. Govt. Printing Office), 977-985.
Moorhouse, W. W., 1959. The Study of Rocks in Thin Section: New York (Harper and Row).

Okada, H., and Bukry, D., 1980. Supplementary modification and introduction of code numbers to the low-latitude coccolith biostratigraphic zonation (Bukry, 1973; 1975). Mar. Micropaleontol., 5:321325.

Srinivasan, M. S., and Kennett, J. P., 1981. Neogene planktonic foraminiferal biostratigraphy: Equatorial to Subantarctic South Pacific. Mar. Micropaleontol., 6:499-534.

Wentworth, C. K., 1922. A scale of grade and class terms for clastic sediments. J. Geol., 30:377-392.

Wentworth, C. K., and Williams, H., 1932. The classification and terminology of the pyroclastic rocks. Bull. Nat. Res. Coun., 89:1953.

Williams, H., Turner, F. J., and Gilbert, C. M., 1954. Petrography: an Introduction to the Study of Rocks in Thin Section: San Francisco (W. H. Freeman and Co.).

Date of Initial Receipt: 24 January 1985 Date of Acceptance: 9 March 1985 


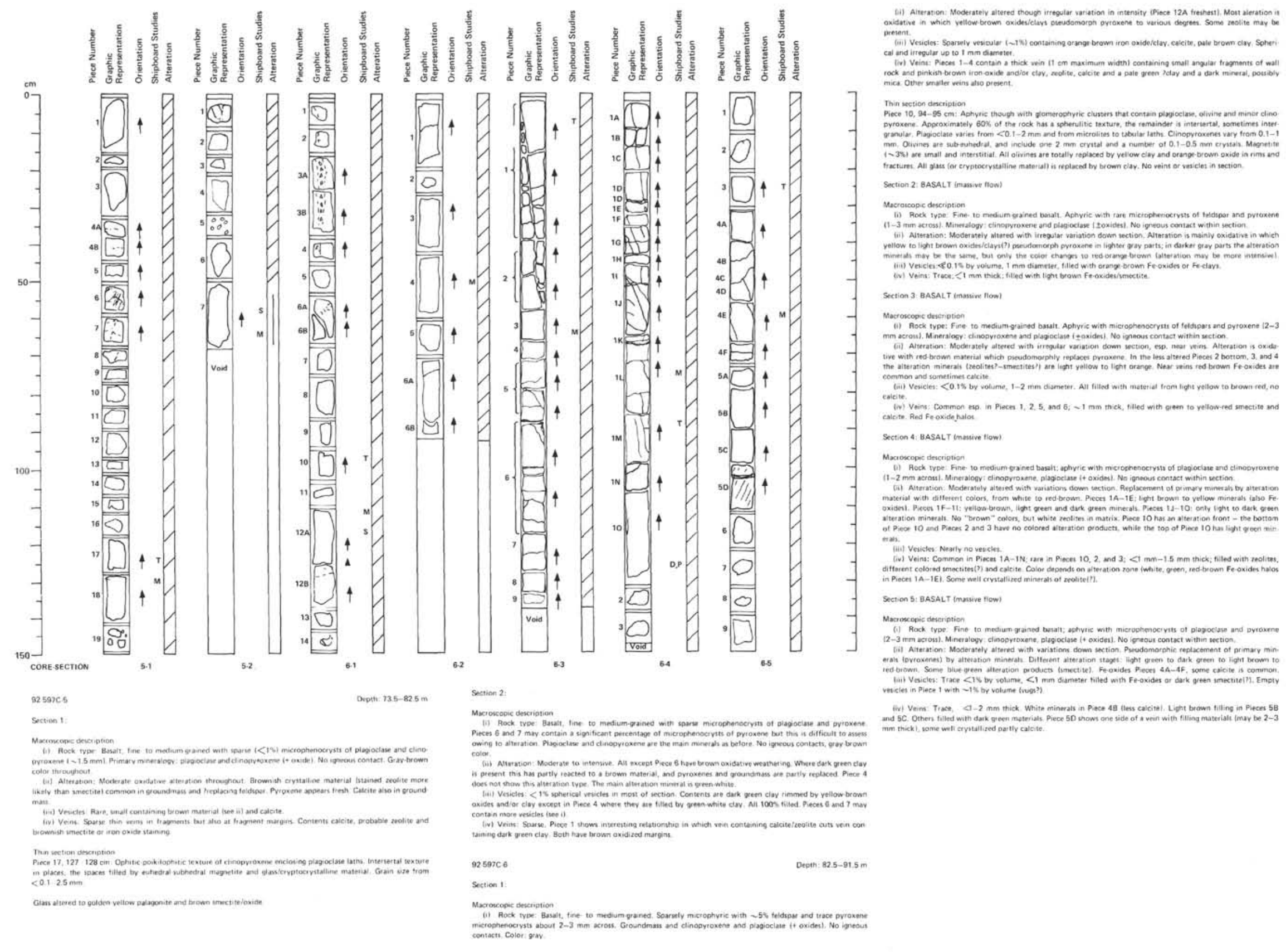




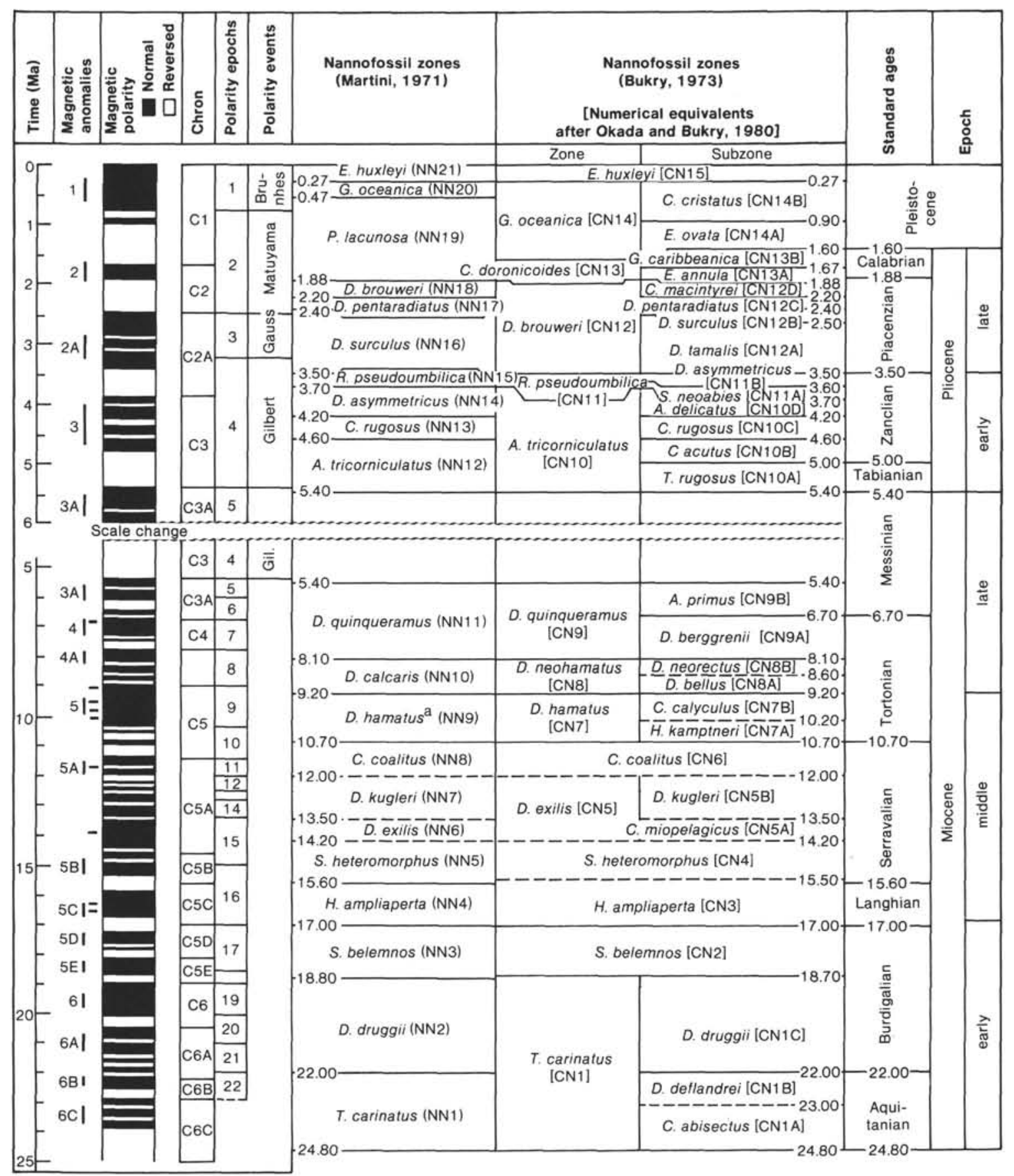

Figure 13. Nannofossil zonation used for Leg 92 biostratigraphy. From Haq (1984). 


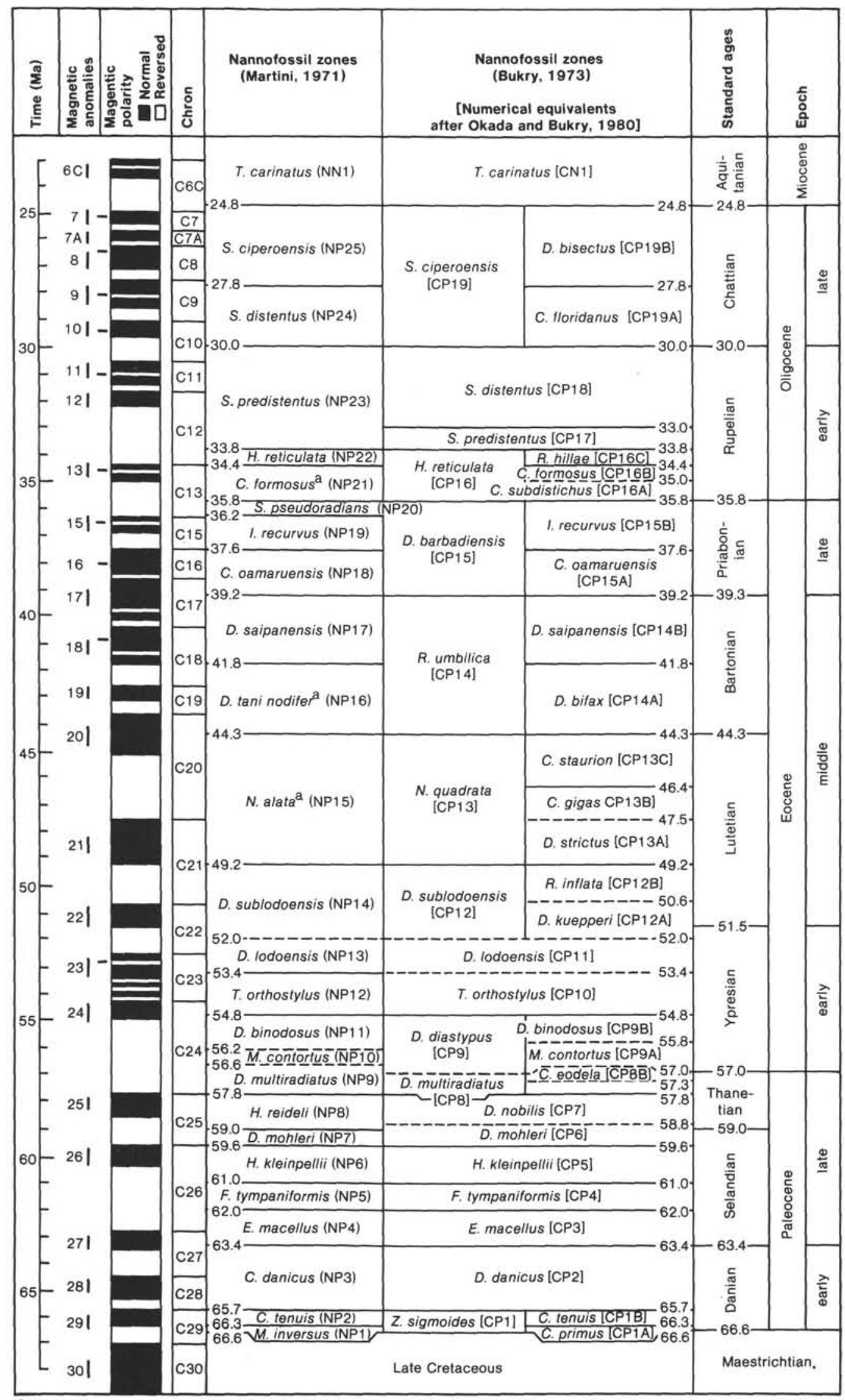

${ }^{\text {a }}$ Modified

Figure 13 (continued). 


\begin{tabular}{|c|c|c|c|c|c|}
\hline & & $\begin{array}{l}\text { Tropical } \\
\text { zonation }\end{array}$ & $\begin{array}{l}\text { Age } \\
\text { (Ma) }\end{array}$ & & Datum \\
\hline \multicolumn{2}{|c|}{ Pleistocene } & N22 & \multirow{4}{*}{$\leftarrow 3.1$} & \multirow{2}{*}{ F.A. } & \\
\hline \multirow{3}{*}{ Pliocene } & late & N21 & & & \multirow{2}{*}{ G. tosaensis } \\
\hline & \multirow{2}{*}{ early } & $\mathrm{N} 19-20$ & & F.A. & \\
\hline & & N19 & & \multirow[b]{2}{*}{ F.A. } & \\
\hline \multirow{15}{*}{ 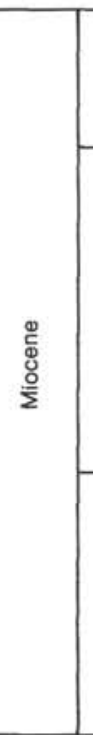 } & \multirow{3}{*}{ late } & N18 & \multirow{5}{*}{$\begin{array}{l}\longleftarrow 4.8 \\
\longleftarrow 5.0 \\
\longleftarrow 6.2 \\
\longleftarrow 7.7 \\
\longleftarrow 10.0 \\
\longleftarrow 11.2\end{array}$} & & S. dehiscens \\
\hline & & $\mathrm{N} 17 \frac{\mathrm{B}}{\mathrm{A}}$ & & $\begin{array}{l}\text { F.A. } \\
\text { F.A. } \\
\text { F.A. }\end{array}$ & $\begin{array}{l}\text { G. tumida tumida } \\
\text { P. primalis } \\
\text { G. plesiotumida }\end{array}$ \\
\hline & & N16 & & F.A. & N. acostaensis \\
\hline & \multirow{7}{*}{ middle } & N15 & & L.A. & G. siakensis \\
\hline & & N14 & & F.A. & \multirow{3}{*}{$\begin{array}{l}\text { G. nepenthes } \\
\text { G. lobata/robusta }\end{array}$} \\
\hline & & $\mathrm{N} 13$ & \multirow{5}{*}{$\begin{array}{l}\leftarrow 12.0 \\
\leftarrow 12.4 \\
\leftarrow 13.9 \\
\longleftarrow 14.7 \\
\leftarrow 15.3 \\
\leftarrow 160\end{array}$} & \multirow{2}{*}{ L.A. } & \\
\hline & & N12 & & & \\
\hline & & N11 & & C... & ब \\
\hline & & N10 & & F.A. & G. praetohsi \\
\hline & & N9 & & $F . A$ & G. peripheroacuta \\
\hline & \multirow{5}{*}{ early } & N8 & \multirow{3}{*}{$\begin{array}{l}\leftarrow 17.2 \\
\longleftarrow 18.0\end{array}$} & $F . A$. & Orbulina spp. \\
\hline & & N7 & & FA. & G. sicanus \\
\hline & & N6 & & L.A. & C. dissimillis \\
\hline & & N5 & \multirow{3}{*}{$\begin{array}{l}\longleftarrow 18.6 \\
\leftarrow 20.5 \\
\leftarrow 22.2\end{array}$} & F.A. & G. insueta \\
\hline & & & & L.A. & G. kugleri \\
\hline \multirow{2}{*}{\multicolumn{2}{|c|}{$\begin{array}{l}\text { late } \\
\text { ligocene }\end{array}$}} & N4 $\frac{\mathrm{O}}{\mathrm{A}}$ & & FA. & G. dehiscens \\
\hline & & P22 & $\longleftarrow 25.0$ & F.A. & Globigerinoides spp. \\
\hline
\end{tabular}

Figure 14. Foraminifer zonation used for Leg 92 biostratigraphy. From Kennett and Srinivasan (1983). 